\title{
COMMENT: Ungulate herbivory of willows on Yellowstone's northern winter range: Response to Singer et al. (1994)
}

\author{
FREDERIC H. WAGNER, RICHARD B. KEIGLEY, AND CARL L. WAMBOLT
}

\begin{abstract}
Authors are director of Ecology Center, assacinte dean, College of Natural Resources, and professor in Dept. of Fisheries and Wildlife, Uiah State Univ, Logan, 84322-5205; research biologist, National Biological Service, Yellowstone Nat. Park, Wyo., 82190; professor of range science, Dept. of Animal and Range Sciences, Montana State Univ., Bozeman, 59717.
\end{abstract}

In a recent JRM article, Singer et al. (1994) report results of a willow (Salix spp.) study on the northern (ungulate winter) range of Yellowstone National Park (YNP) and immediate vicinity. The authors measured production, forage quality, moisture stress, and tannin content of growth shoots, all in relation to ungulate browsing, browsing-induced architectural variation, and altitude. In our view, the evidence presented does not support a number of the major inferences drawn, and in fact points to what in our judgment are more probable ones.

\section{Key Findings by Singer et al. 1994}

The authors examined shrubs of 8 willow species in 42 plant communities, and classified the latter according to shrub height: 10 "height-suppressed" ( $\leqslant 80 \mathrm{~cm}), 11$ "intermediate" (81-120 $\mathrm{cm})$, and 21 "tall" ( $\geq 121 \mathrm{~cm})$. Shrub height was correlated with alcitude: $80 \%$ of suppressed and all intermediate stands occurred between 1,800 and $2,200 \mathrm{~m}$ elevation, $60 \%$ of tall stands occurred above 2,200 $\mathrm{m}$ (Singer et al. 1994: Fig. 1). All stands above 2,400 $\mathrm{m}$ were tall.

Winter browsing intensity (\% leader use) was inversely related to plant height among the 3 classes. With 1 species excluded because of its growth characteristics, height-suppressed willows had lower condensed tannin concentrations in their growth shoots $(42.7 \mathrm{mg} / \mathrm{g})$ than did intermediate and tall $(50.5 \mathrm{mg} / \mathrm{g})$. Annual, aboveground production measured in $\mathrm{g} / \mathrm{m}^{2}$ was positively correlated with the 3 height classes, and with elevation.

Singer et al. (1994) state "Lower secondary compound concentrations were apparently of overriding importance in the higher preference for suppressed willows than were nutrients or digestibility." The authors concluded that "... many browse-suppressed willows grew on sites with lower growth potential than did tall or intermediate height willows ... [which,] coupled with less defense chemistry compounds ... [made them] more vulnera-

Manuscript accepted S Iul. 1995.

Edifor's Note: The authors of Singer et al. (1994) have been offered an opportuniry for a reburtal. This rabunal will be published in a future issue. ble to the effects of large herbivore browsing ... contributing to height suppression ..." The authors speculated "... that a more xeric climate, lowered water tables, and/or changes in hydrological patterns contributed to the willow declines and changes in chemistry production on the northern winter range ..." during YNP history. Most of the declines "... apparently occurred during the 1920s through 1940s."

\section{Our Objections and Alternate Inferences}

Our major point is that a number of things-elevation, precipitation, willow-stand height, numbers of elk wintering, browsing intensity, concentration of secondary compounds, annual aboveground production-are covarying and we do not accept this paper's assumptions about where cause and effect lie. We enumerate our points:

(1) The paper concludes that the suppressed plants are more heavily browsed because they are less-well-defended chemically. But we suggest that the inverse causation is more probable. The better-defended, more-lightly-browsed, tall plants predominate at the higher elevations; the less-defended, more-heavily browsed plants predominate at lower levels. In YNP, winter snow depth is a function of elevation forcing elk to lower levels. The paper makes this point. Hence, it is to be expected that browsing intensity would be higher at low elevations.

Moreover, as Singer et al. (1994) comment and the plantdefense literature reports abundantly (e.g. Rhoades 1979, Cates et al. 1983, Louda and Rodman 1983), stresses on plant vigor (including heavy clipping) impair their ability to produce secondary compounds. It seems probable that the heavier browsing of YNP willows at lower elevations inhibits the hedged plants' ability to produce tannins, and explains their low content. The paper's evidence on willows inside and outside exclosures in YNP supports this interpretation. Condensed-tannin concentration in browse-suppressed willows outside 3 exclosures was lower $(30.3 \mathrm{mg} / \mathrm{g})$ than in unbrowsed plants inside exclosures $(38.1 \mathrm{mg} / \mathrm{g})$.

Thus we propose that tannin production in suppressed plants was impaired by heavier browsing due to higher elk densities. We 
consider this a more likely scenario than the paper's hypothesis that site-related lower tannin production in suppressed plants attracted heavier browsing and was the "ultimate" cause of YNP's willow decline.

(2) The paper concludes, as in the above quotation, that some sites had "lower growth potential" and "less than optimum growth conditions." Such sites are implied to impair tannin production, atract heavy browsing, and contribute to willow decline.

However, the paper does not make clear the basis on which the judgments of site condition are made and the reader must infer the connections. Once again, several parameters are covarying: elevation, precipitation, browsing intensity, primary production, and tannin concentration. Inference on site condition from any 1 of these variables is confounded by the covariates.

One basis for judging site condition might have been annual aboveground production which was lower in suppressed stands than in intermediate and tall. But production was calculated by counting stems per plant and measuring them. Stature and degree of browsing would likely influence the size and number of shoots. Hence annual aboveground production, as measured by Singer et al. (1994), is not an unequivocal measure of site condition.

Three lines of evidence suggest that site condition was not a significant determinant of browsing intensity. First, the photographic evidence (Kay 1990) clearly shows widespread elimination of riparian shrub zones along stream banks, sites normally considered good willow habitat. Second, the paper's exclosure evidence, where site condition was a constant, showed differences in plant stature and tannin content associated with browsing and with profection. And third, the study showed water stress in suppressed plants to be lower than that in intermediate and tall ones.

(3) Singer et al. (1994) draw chronological inferences which are entirely unsupported by the evidence. The unproven inference of suppressed tannin production on what are taken to be suboptimum sites is coupled with evidence of "More xeric growth conditions this century' than last ... may explain the [emphasis ours] low growth rates and lower chemical defenses against ungulate herbivory ..." This is implied to have induced heavy browsing and sharp decline in willows since YNP formation in 1872.

Our first point is that this is pure surmise. There is no evidence that chemical defenses have been lower in this century than last. The use of the definite article in the above quote from the Abstract, and used in a similar statement in the Conclusions section, will imply to the reader, whether intended or not, that decline in defenses is an established reality. This is especially likely for someone reading only the Abstract and not examining the paper's evidence critically.

Even if it were true that chemical defenses had declined in this century, it doesn't necessarily follow that it is responsible for the heavier browsing. As above, cause and effect can be inverted: A greatly increased wintering elk herd following park formation could have placed heavier browsing pressure on the northernrange willows and suppressed their ability to produce defenses.

Moreover the evidence on whether or not there has been a climate change in this century is difficult to interpret. Singer et al. (1994) cite Houston (1982) as reporting a $0.5-1.0^{\circ} \mathrm{C}$ temperature increase in this century and a 1-2 mm decline in annual precipitation. Houston's records for Mammoth Hot Springs only go back to 1887, hardly sufficient to compare the 1800 s with the 1900 s. And while a $0.5-1.0^{\circ} \mathrm{C}$ change in a $4.0^{\circ} \mathrm{C}$ mean annual tempera- ture would be substantial, a $1-2 \mathrm{~mm}$ change in $>400 \mathrm{~mm}$ mean annual precipitation could not be measurable with standard rain gear, demonstrable statistically in the face of typical year-to-year variation, or detectable by the plants.

Houston's (1982:103-104) 15-year precipitation moving averages complicate trend interpretations, as he comments. There does appear to have been a significant precipitation decline during the 1930s, and Singer et al. (1994) infer that much of the willow decline occurred from 1920 through the 1940s. However, Smith et al. (1915) were already reporting that willows were "trimmed off to mere stumps" in 1915. A 1921 Warren (1926) photograph shows heavy willow hedging on the northern range. Clearly, heavy elk use on willows began before 1920 .

Singer et al. (1994) also suggest that decline of beaver in YNP and associated changes in hydrology may have reduced the area of sites suitable for willow. While we do not see any evidence for, nor need to implicate, reduced chemical defense and associated increase in browsing intensity, we do agree that beaver decline could have been a cause of willow decline. Beaver were extremely abundant in the park in the decades following its establishment in 1872 (Kay 1990). Skinner (1927) estimated their numbers still at "about 10,000" by the early 1900s. Their scarcity today must result in fewer dams, ponds, and riparian areas for willow habitat.

However, a succession of authors (e.g. Bailey 1930, Wright and Thompson 1935, Jonas 1955. Kay 1990) have attributed the beaver decline to elimination of willow and aspen (Populus tremuloides), staple beaver food and building material, by heavy elk browsing. Hence elk browsing may have served as positive feedback on willow decline. If willow removal reduced beaver populations and consequently beaver-produced riparian habitat, the willow habitat reduction could have accelerated willow decline. In the Singer et al. (1994) terminology, elk would have been both the ultimate and proximate factors on willow decline.

\section{Conclusions}

We agree the Singer et al. (1994) evidence indicates that suppressed willows on YNP's northern winter range have lower tannin levels than intermediate-height and tall willows. However, we contend that there is no evidence from this study supporting the inferences that lower tannins were the primary cause attracting heavier browsing, and that hedged plants produced less tannins because they occurred on suboptimal sites for willow growth. We do not suggest that unfavorable site conditions might not affect tannin production to some degree. We simply conclude that it has not been demonstrated in this study. We are also well aware of the evidence in the literature that plant defensive chemistry can influence herbivores' feeding behavior, but again it is not demonstrated in this case.

The suppression of willow stature on the northern range is an inverse function of elevation as are the numbers of wintering elk. The more severe hedging at lower elevations is more likely the result of greater ungulate numbers and consequent heavier browsing. We suggest further that the lower tannin concentrations in suppressed plants are more likely the result of stress induced by heavier browsing, an inference supported by the differences in tannin concentration in plants inside and outside exclosures.

We contend further that there is no evidence supporting the Singer et al. (1994) surmise that chemical defenses have declined in the present century-referred to as "the ... lower chemical 
defenses" and "the ... changes in chemistry production" [emphases added]-because of changed growth conditions; and further that this has been the "ultimate factor" inducing willow declines for which elk browsing is acknowledged as the "proximate" cause. Even if tannins have declined, there is no evidence that the content of tall plants is sufficient to deter browsing. And the hedged plants are not undefended. Their tannin content averaged $85 \%$ that of intermediate and tall plants $(42.7 / 50.5 \mathrm{mg} / \mathrm{g} \mathrm{x}$ 100).

We also question whether total tannins are a good index to animal acceptance of tannin-containing forage. We suggest individual tannins play a significant role in acceptance (Provenza et al. 1994), just as individual terpenes do in sagebrush taxa found on the northern Yellowstone winter range (Bray et al. 1991).

Any suggestion that the northern-range willow decline, so vividly documented by the photographic record (cf. Kay 1990), is the result of reduced chemical defenses attracting heavier browsing must square with the fact that ungulate browsing, primarily elk: has impacted and/or reduced all of the woody plant species on the northem range. Elk have been so hard-pressed for winter forage that they have high-lined spruce (Picea engelmannii), which is among the least palatable of woody plants to ungulates. The prevailing evidence remains that the progressive decline of woody vegetation on the northern range, especially willow, has been induced by a wintering elk herd that has greatly increased since establishment of YNP.

\section{Literature Cited}

Bailey, J. 1930. Animal life of Yellowstone National Park. C. Thomas and Co., Springfield, Ml.:241 pp.

Bray, R.O., C.L. Wambolt, and R.G. Kelsey. 1991. Influence of sagebrush terpenoids on mule deer preference. J. Chemical Ecol. 17:2053-2052.
Cates, R.G., R.A. Redak, and C.B. Henderson. 1983. Patterns in defensive natural product chemistry: Douglas fir and western spruce budworm interactions. Pp. 3-19 In: P.A. Hedin (ed.). Plant resistance to insects. Amer. Chem. Soc., Washington, D.C.: VIII + 375 pp.

Houston, D.B. 1982. The northern Yellowstone elk/Ecology and management. Macmillan Publ. Co., Inc., N.Y.:XXII + 474 pp.

Jonas, R.J. 1955. A population and ecological study of the beaver (Castor canadensis) in Yellowstone National Park. Univ. Idaho M.S. Thesis: 193 pp.

Kay, C.E. 1990. Yellowstone's northern elk herd: A critical evaluation of the "natural regulation" paradigm. Utah State Univ. Ph.D. Dissert:XVI $+490 \mathrm{pp}$.

Louda, S.M. and J.E. Rodman. 1983. Concentration of glucosinolates in relation to habitat and herbivory for the native crucifer Cardamine cordifolia. Biochem. System. and Ecol. 11:199-207.

Provenza, F.D., E.A. Burritt, T.P. Clausen, J.P. Bryant, P.B. Reichardt, and R.A. Distel. 1990. Conditioned flavor aversion: A mechanism for goats to avoid condensed tannins in blackbrush. Amer. Natur. 136:810-828.

Rhoades, D.F. 1979. Evolution of plant chemical defense against herbivores. Pp. 3-54 In: G.H. Rosenthal and D.H. Janzen (eds). Herbivores/Their interaction with secondary plant metabolites. Academic Press, N.Y.: XI +718 pp.

Singer, F.I., L.C. Mark, and R.C. Cates. 1994. Ungulate herbivory of willows on Yellowstone's northem winter range. J. Range Manage. 47:435-443.

Skinner, M.P. 1927. The predatory and fur-bearing animals of the Yellowstone National Park. Roosevelt Wildl. Bull. 4:163-281.

Smith, C.L., A.A. Simpson, and V. Bailey. 1915. Investigation of the elk herds in the Yellowstone Park region of Wyoming, Montana, and Idaho. A joint report of investigations carried on by the Forest Service and Biological Survey during the summer of 1915. U.S.D.A. Forest Serv. and U.S. Bureau Biol. Surv. Unpub. Rept.: I + 56 pp. in Yellowstone N.P. Library.

Warren, E.R. 1926. A study of the beaver in the Yancy region of Yellowstone National Park. Roosevelt Wildl. Ann. 1:1-191.

Wright, G.H. and B.H. Thompson. 1935. Fauna of the national parks of the United States. U.S. Nat. Park Serv. Fauna Series 2:142 pp. 